\title{
Correlation, by multivariate statistical analysis, between the scavenging capacity against reactive oxygen species and the bioactive compounds from frozen fruit pulps ${ }^{3}$
}

\author{
Correlação, por análise estatística multivariada, entre desativação de espécies \\ reativas de oxigênio e compostos bioativos de polpas de frutas congeladas
}

\author{
Lizziane Cynara VISSOTTO ${ }^{1}$, Eliseu RODRIGUES ${ }^{1}$, Renan Campos CHISTÉ ${ }^{1}$, \\ Marta de Toledo BENASSI ${ }^{2}$, Adriana Zerlotti MERCADANTE ${ }^{1 *}$
}

\begin{abstract}
The contents of total phenolic compounds (TPC), total flavonoids (TF), and ascorbic acid (AA) of 18 frozen fruit pulps and their scavenging capacities against peroxyl radical ( $\left.\mathrm{ROO}^{*}\right)$, hydrogen peroxide $\left(\mathrm{H}_{2} \mathrm{O}_{2}\right)$, and hydroxyl radical $\left({ }^{\circ} \mathrm{OH}\right)$ were determined. Principal Component Analysis (PCA) showed that TPC (total phenolic compounds) and AA (ascorbic acid) presented positive correlation with the scavenging capacity against ROO*, and TF (total flavonoids) showed positive correlation with the scavenging capacity against ${ }^{\circ} \mathrm{OH}$ and $\mathrm{ROO}{ }^{\bullet} \mathrm{However}$, the scavenging capacity against $\mathrm{H}_{2} \mathrm{O}_{2}$ presented low correlation with $\mathrm{TF}$ (total flavonoids), TPC (total phenolic compounds), and AA (ascorbic acid). The Hierarchical Cluster Analysis (HCA) allowed the classification of the fruit pulps into three groups: one group was formed by the açai pulp with high TF, total flavonoids, content (134.02 mg CE/100 g pulp) and the highest scavenging capacity against $\mathrm{ROO}^{\bullet}, \bullet^{\circ} \mathrm{OH}$ and $\mathrm{H}_{2} \mathrm{O}_{2}$; the second group was formed by the acerola pulp with high TPC, total phenolic compounds, (658.40 mg GAE/100 g pulp) and AA , ascorbic acid, (506.27 mg/100 g pulp) contents; and the third group was formed by pineapple, cacao, caja, cashew-apple, coconut, cupuaçu, guava, orange, lemon, mango, passion fruit, watermelon, pitanga, tamarind, tangerine, and umbu pulps, which could not be separated considering only the contents of bioactive compounds and the scavenging properties.
\end{abstract}

Keywords: bioactive compounds; antioxidant capacity; fruit pulp.

\section{Resumo}

Os teores de compostos fenólicos totais (CFT), flavonoides totais (FT) e ácido ascórbico (AA) foram determinados em 18 polpas de frutas congeladas, assim como a capacidade antioxidante na desativação do radical peroxila ( $\mathrm{ROO})^{*}$, peróxido de hidrogênio $\left(\mathrm{H}_{2} \mathrm{O}_{2}\right)$ e radical hidroxila $\left({ }^{\circ} \mathrm{OH}\right)$. De acordo com a Análise de Componentes Principais (ACP), CFT e AA apresentaram correlação positiva com a capacidade de desativar o ROO` e o teor de FT apresentou correlação positiva com a capacidade de desativar o ${ }^{\circ} \mathrm{OH}$ e ROO`. Entretanto, a capacidade de desativar o $\mathrm{H}_{2} \mathrm{O}_{2}$ apresentou baixa correlação com FT, CFT e AA. A Análise Hierárquica de Agrupamentos (HCA) permitiu a separação das polpas de frutas em três grupos: o primeiro formado pela polpa de açaí, com elevado teor de FT (134,02 mg EC/100 g polpa) e maior desativação do $\mathrm{ROO}^{*},{ }^{\circ} \mathrm{OH}$ e $\mathrm{H}_{2} \mathrm{O}_{2}$; o segundo pela polpa de acerola, com elevado teor de CFT (658,40 mg EAG/100 g polpa) e de AA (506,27 mg/100 g polpa); e o terceiro grupo formado pelas polpas de abacaxi, cacau, cajá, caju, coco, cupuaçu, goiaba, laranja, limão, manga, maracujá, melancia, pitanga, tamarindo, tangerina e umbu, que não puderam ser separadas considerando apenas os teores dos compostos bioativos e a propriedades antioxidantes.

Palavras-chave: compostos bioativos; capacidade antioxidante; polpa de fruta.

\section{Introduction}

Results of epidemiological studies showed an inverse association between a diet rich in fruits and vegetables and the decreased risk of developing chronic degenerative diseases. This relationship is attributed to the presence of bioactive compounds, including phenolic compounds, carotenoids, and vitamins $\mathrm{C}$ and $\mathrm{E}$ (GARCÍA-ALONSO et al., 2004). These compounds are able to protect biomolecules, such as lipids and proteins, against the oxidative damage induced by reactive oxygen (ROS) and nitrogen species (RNS).

In most of the studies, the antioxidant capacity of fruits is determined using methods based on the deactivation of non-biological radicals, such as 2,2'-azinobis-(3ethylbenzothiazoline-6-sulfonic acid) radical $\left(\right.$ ABTS $\left.^{\bullet+}\right)$ and 2,2-diphenyl-1-picrylhydrazyl radical (DPPH $\left.{ }^{\bullet}\right)$ (KUSKOSKI et al., 2006; MELO et al., 2008a, b; SANTOS et al., 2008, 2010; BARRETO; BENASSI; MERCADANTE, 2009; ROP et al., 2010; CONTRERAS-CALDERÓN et al., 2011; MEDINA et al., 2011; FU et al., 2011), which are not present in the biological system and have different properties as compared to the ROS produced in the human body. There are some data available in the literature concerning the scavenging capacity of fruit pulps against peroxyl radicals (ROO•) (WANG; CAO;

Received 2/8/2012

Accepted 4/10/2012 (00Q5812)

${ }^{1}$ Department of Food Science, Faculty of Food Engineering, University of Campinas - UNICAMP, CEP 13083-862, Campinas, SP, Brazil, e-mail: azm@fea.unicamp.br

${ }^{2}$ Department of Food Science and Technology, State University of Londrina - UEL, CP 6001, CEP 86051-970, Londrina, PR, Brazil

3 Trabalho agraciado em $1^{\circ}$ lugar (classificação geral) com o Prêmio Leopoldo Hartmanno XXIII Congresso Brasileiro de Ciência e Tecnologia de Alimentos

(01 a 4 de maio de 2012), Campinas, SP, Brasil.

${ }^{*}$ Corresponding author 
PRIOR, 1996; WU et al., 2004); however, there is no information regarding the scavenging capacity of frozen fruit pulps against other ROS with physiological importance, such as hydrogen peroxide $\left(\mathrm{H}_{2} \mathrm{O}_{2}\right)$ and hydroxyl radical $\left({ }^{\circ} \mathrm{OH}\right)$.

Brazil is the third largest producer of fruits in the world. In 2010, the production reached over 42 million tons (KIST et al., 2012), from which about $53 \%$ were destined for processing and $47 \%$ for fresh consumption. Currently, the Brazilian production is focused on tropical, subtropical, and temperate fruits due to the large territorial extension of the country, as well as the soil and favourable climatic conditions (XEYLA, 2009). Fruits are perishable; consequently they deteriorate quickly, within a few days, making their in natura trading over long distances difficult. Therefore, the production of frozen fruit pulps has become an option to reap the benefits of fruits, to facilitate trading them in places where there is no production, and to preserve them for a longer period after harvest. Therefore, the contents of total phenolic compounds, total flavonoids, and ascorbic acid of 18 frozen fruit pulps were determined, and these values were correlated applying multivariate statistical analysis to the antioxidant capacity against the oxidizing effects of $\mathrm{ROO}^{\bullet}, \mathrm{H}_{2} \mathrm{O}_{2}$ and ${ }^{\bullet} \mathrm{OH}$.

\section{Materials and methods}

\subsection{Chemicals}

Folin-Ciocalteu reagent, catechin (96.0\%), gallic acid (98.0\%), AAPH ( $\alpha, \alpha^{\prime}$-azodiisobutyramidinedihydrochloride), ascorbic acid (99.0\%), lucigenin, fluorescein, luminol, and Tris-(hydroxymethyl) aminomethane were purchased from Sigma-Aldrich (Steinheim, Germany). Trolox (6-hydroxy2,5,7,8-tetramethylchromane-2-carboxylic acid) (99.5\%) was purchased from Fluka ChemieGmbH (Steinheim, Germany). Monosodium phosphate $\left(\mathrm{NaH}_{2} \mathrm{PO}_{4}\right)$, disodium phosphate
$\left(\mathrm{Na}_{2} \mathrm{HPO}_{4}\right)$, hydrogen peroxide $\left(\mathrm{H}_{2} \mathrm{O}_{2}\right)$, aluminium chloride $\left(\mathrm{AlCl}_{3}\right)$, sodium hydroxide $(\mathrm{NaOH})$, sodium nitrite $\left(\mathrm{NaNO}_{2}\right)$, and DMSO (dimethyl sulfoxide) were purchased from Synth (São Paulo, Brazil). DCFI (2-6-dichlorophenolindophenol) was purchased from Nuclear (São Paulo, Brazil) and sodium carbonate $\left(\mathrm{Na}_{2} \mathrm{CO}_{3}\right)$ from Ecibra (São Paulo, Brazil).

A microplate reader (Synergy Mx, Biotek, Vermont, USA) for fluorescence, UV-vis and, chemiluminescence measurements, equipped with a thermostat, was used for all the assays. All measurements were performed in triplicate.

\subsection{Material and fruit pulp preparation}

Two batches of each the frozen fruit pulp (100 g) (Table 1) were acquired from the same manufacturer in Campinas, São Paulo (Brazil) and stored at $-80^{\circ} \mathrm{C}$. The samples were prepared by mixing four packages of $100 \mathrm{~g}$ of fruit pulp from the same batch, followed by homogenisation with water in the proportion of $100 \mathrm{~g}$ of pulp and $250 \mathrm{~mL}$ of ultrapure water $(1: 2.5, \mathrm{w} / \mathrm{v})$ in a domestic blender (according to the manufacturer instructions), and centrifuging at $6450 \mathrm{~g}$ for 20 minutes at $20^{\circ} \mathrm{C}$. The supernatant (aqueous extract) was used to analyze both the bioactive compounds and antioxidant capacity.

\subsection{Bioactive compounds determination}

\section{Total phenolic compounds}

The content of total phenolic compounds (TPC) of each frozen fruit pulp was determined using the Folin-Ciocalteu colorimetric method, according to Singleton and Rossi (1965) adapted to microplate reader. The reaction mixture $(300 \mu \mathrm{L})$ contained the Folin-Ciocalteu reagent, the fruit pulp extracts at different concentrations ( 1 to $83 \mathrm{mg} / \mathrm{L}$ ), and $\mathrm{Na}_{2} \mathrm{CO}_{3}(7 \%)$. The quantification was performed at $765 \mathrm{~nm}$ from an analytical curve

Table 1. Common and scientific names, fruit origin, and composition of the frozen fruit pulps analyzed, commercialized in Brazil.

\begin{tabular}{|c|c|c|c|}
\hline Common name & Scientific name & Fruit origin & Composition \\
\hline Açai & Euterpe oleracea Mart & North Brazil & açai and water \\
\hline Acerola & Malpighia emarginata DC & West Indies & whole acerola \\
\hline Cacao & Theobroma cacao L. & Amazon & whole cacao \\
\hline Caja & Spondias lutea L. & North and Northeast Brazil & whole caja \\
\hline Cashew-apple & Anacardium occidentale L. & North eastern coast & whole cashew-apple \\
\hline Coconut & Cocus nucifera L. & Archipelagos of the Pacific Ocean & whole coconut \\
\hline Cupuaçu & Theobroma grandiflorum Schum & Amazon Forest & whole cupuaçu \\
\hline Guava & Psidiumgua java L. & Central America & whole guava \\
\hline Lemon & Citrus spp. & Southeast Asia & whole lemon \\
\hline Mango & Mangifera indica $\mathrm{L}$. & India & whole mango \\
\hline Orange & Citrussinensis Osbeck & SoutheastAsia & whole orange \\
\hline Passionfruit & Passiflora edulis Sims & Northeast Brazil & whole passion fruit \\
\hline Pineapple & Ananas comosus (L.) Merrill & Central America/Northeast Brazil & whole pineapple \\
\hline Pitanga & Eugenia unifloraL. & Brazil & whole pitanga \\
\hline Tamarind & Tamarindus indica L. & India & whole tamarind \\
\hline Tangerine & Citrus reticulata Blanco & Southeast Asia & whole tangerine \\
\hline Umbu & Spondias tuberosa Arr.Cam & Northeast Brazil & whole umbu \\
\hline Watermelon & Citrullus vulgaris Schrad & India & whole watermelon \\
\hline
\end{tabular}


(measurements in duplicate) using gallic acid as a standard with concentrations ranging from 12.5 to $150 \mathrm{mg} / \mathrm{L}$. The analytical curve was linear $\left(\mathrm{r}^{2}=0.997\right)$, the limit of detection was $8 \mathrm{mg} / \mathrm{L}$, and the limit of quantification was $25 \mathrm{mg} / \mathrm{L}$. The results were expressed as milligrams of gallic acid equivalent (GAE) per $100 \mathrm{~g}$ of pulp. The contribution of AA to the Folin-Ciocalteau reaction was not evaluated in the present study.

\section{Total flavonoids}

The quantification of total flavonoids (TF) was carried out using the colorimetric assay described by Zhishen, Mengcheng and Jianming (1999), with adaptations for the microplate reader. The reaction mixture $(300 \mu \mathrm{L})$ contained at final concentrations the fruit pulp extracts at different concentrations (1.2 to $100 \mathrm{mg} / \mathrm{L}), \mathrm{NaNO}_{2}(5 \%), \mathrm{AlCl}_{3}(10 \%)$, and $\mathrm{NaOH}(1 \mathrm{M})$. The quantification was performed at $510 \mathrm{~nm}$ from an analytical curve (measurements in duplicate) using catechin as a standard with concentrations ranging from 12.5 to $200 \mathrm{mg} / \mathrm{L}$. The analytical curve was linear $\left(r^{2}=0.998\right)$, the limit of detection was $10 \mathrm{mg} / \mathrm{L}$, and the limit of quantification was $30 \mathrm{mg} / \mathrm{L}$. The results were expressed as milligrams of catechin equivalent (CE) per $100 \mathrm{~g}$ of fruit pulp.

\section{Ascorbic acid}

The ascorbic acid (AA) contents were determined using the Tillman's method (INSTITUTO..., 2004). An oxalic acid solution (1\%) was added $(50 \mathrm{~mL})$ to the fruit pulp extract and kept in the dark for 15 minutes. The quantification was performed by titration with $0.2 \%$ DCFI solution and compared to the AA standard titration $(50 \mathrm{mg} / 100 \mathrm{~mL})$. The results were expressed as milligrams of ascorbic acid (AA) per $100 \mathrm{~g}$ of fruit pulp.

\subsection{Antioxidant capacity against reactive oxygen species (ROS)}

The assays were carried out using a microplate reader (Synergy Mx, BioTek, Vermont, USA) for fluorescence, UV-vis, and luminescence measurements, equipped with a thermostat set at $37{ }^{\circ} \mathrm{C}$ and dual reagent dispenser. The results of $\mathrm{H}_{2} \mathrm{O}_{2}$ and $\cdot \mathrm{OH}$ were expressed as $\mathrm{IC}_{50}(\mu \mathrm{g} / \mathrm{mL})$, i.e., concentration necessary to inhibit oxidation by $50 \%$, calculated using nonlinear regression analysis and the GraphPad Prism 5 software.

\section{Peroxyl radical (ROO•) scavenging assay}

The ROO• scavenging capacity was determined by monitoring the decay of fluorescence of fluorescein as result of $\mathrm{ROO}^{\bullet}$-induced oxidation of fluorescein (HUANG et al., 2002). The ROO` species were generated by thermo-decomposition of AAPH at $37^{\circ} \mathrm{C}$. The reaction mixtures in the sample wells contained the following reagents at the indicated final concentrations (final volume of $200 \mu \mathrm{L})$ : AAPH $(19 \mathrm{mM})$, fluorescein $(61.2 \mathrm{mM})$, and the extract of fruit pulp at different concentrations ( 6.3 to $125 \mathrm{mg} / \mathrm{L}$ ) and diluted in phosphate buffer (75 mM, pH 7.4). The fluorescence signal was monitored every minute using excitation and emission wavelengths at $485 \mathrm{~nm}$
$528 \mathrm{~nm}$, respectively, for 60 minutes. Trolox was used as positive control $($ Net area $(2 \mu \mathrm{M})=7.4 \pm 0.9$; Net area $(4 \mu \mathrm{M})=13.1 \pm 1.1$, and Net area $(8 \mu \mathrm{M})=22.6 \pm 1.4)($ RODRIGUES et al., 2012). The results were expressed as $\mu \mathrm{mol}$ trolox equivalent and were obtained from the analytical curve of trolox with concentration varying from 12 to $94 \mu \mathrm{M}$.

\section{Hydrogen peroxide $\left(\mathrm{H}_{2} \mathrm{O}_{2}\right)$ scavenging assay}

The $\mathrm{H}_{2} \mathrm{O}_{2}$ scavenging capacity was measured by monitoring the effect of the extracts of fruit pulps on the $\mathrm{H}_{2} \mathrm{O}_{2}$-induced oxidation of lucigenin (GOMES et al., 2007). Reaction mixtures contained the following reagents at final concentrations (final volume of $250 \mu \mathrm{L}$ ): $50 \mathrm{mM}$ Tris- $\mathrm{HCl}$ buffer $\mathrm{pH}$ 7.4, lucigenin $(0.8 \mathrm{mM})$ dissolved in the buffer solution, extract of fruit pulps at different concentrations (10 to $200 \mathrm{mg} / \mathrm{L}$ ) and completely dissolved in Tris- $\mathrm{HCl}$ buffer, and $1 \% \mathrm{H}_{2} \mathrm{O}_{2}$. The assays were performed at $37^{\circ} \mathrm{C}$. The chemiluminescence signal was detected using the microplate reader after 10 minutes of incubation. Ascorbic acid was used as the positive control $\left(\mathrm{IC}_{50}=171 \mu \mathrm{g} / \mathrm{mL}\right)$ (RODRIGUES et al., 2012).

\section{Hydroxyl radical $\left({ }^{\circ} \mathrm{OH}\right)$ assay}

The ${ }^{\bullet} \mathrm{OH}$ scavenging capacity was measured by monitoring the effect of the extracts of fruit pulps on the ${ }^{\circ} \mathrm{OH}$-induced oxidation of luminol (GOMES et al., 2006). The ${ }^{\bullet} \mathrm{OH}$ was generated by the Fenton reaction $\left(\mathrm{FeCl}_{2}-\mathrm{EDTA}-\mathrm{H}_{2} \mathrm{O}_{2}\right)$. The reaction mixtures contained the following reagents at final concentrations (final volume of $250 \mu \mathrm{L})$ : luminol $(20 \mu \mathrm{M})$, extracts of fruit pulps in different concentrations (5 to $100 \mathrm{mg} / \mathrm{L})$, diluted in carbonate buffer ( $\mathrm{pH}$ 10), $\mathrm{FeCl}_{2}$ - EDTA (25 $\mu \mathrm{M}$ and $100 \mu \mathrm{M}$, respectively), and $\mathrm{H}_{2} \mathrm{O}_{2}(3.5 \mu \mathrm{M})$. The assays were performed at $37^{\circ} \mathrm{C}$. The chemiluminescence signal was detected using the microplate reader after 5 minutes of incubation. Gallic acid was used as the positive control $\left(\mathrm{IC}_{50}=0.11 \mu \mathrm{g} / \mathrm{mL}\right)($ RODRIGUES et al., 2012).

\subsection{Statistical analysis}

The contents of bioactive compounds and antioxidant capacity values obtained (mean \pm standard deviation) were analyzed using the Statistica 6.0 software (Statsoft Inc., 2001). Two multivariate exploratory techniques, Principal Components Analysis (PCA) and Hierarchical Cluster Analysis (HCA), were applied to correlate and classify the extracts of frozen fruit pulps using the Statistica 6.0 software. For PCA, the bioactive compounds (total phenolic compounds, total flavonoids, and ascorbic acid) and the scavenging capacity against the reactive oxygen species ( $\mathrm{ROO}^{\bullet}, \mathrm{H}_{2} \mathrm{O}_{2}$ and ${ }^{\circ} \mathrm{OH}$ ) were used as variables in the derivation of the principal components. The HCA hierarchical tree was obtained considering the same variables of PCA, and the extracts were grouped by unweighted pair-group average as the linkage rule considering the Euclidian distance as the coefficient of similarity.

In order to successfully perform the PCA and HCA, some considerations were applied. When ascorbic acid was not detected in the extracts of fruit pulps (açai, cacao, watermelon, 
and umbu), the value was considered as 0 (zero). When the $\mathrm{IC}_{50}$ value was not reached at the highest tested concentration in the $\mathrm{H}_{2} \mathrm{O}_{2}$ scavenging assay, the $\mathrm{IC}_{50}$ values were estimated after fitting the curves of concentration versus inhibition percentage, as did for coconut and watermelon. In addition, the $\mathrm{IC}_{50}$ values obtained in the $\mathrm{H}_{2} \mathrm{O}_{2}$ and ${ }^{\circ} \mathrm{OH}$ scavenging assays were used as the inverse of $\mathrm{IC}_{50}\left(1 / \mathrm{IC}_{50}\right)$ in the data matrix to facilitate the graphical analysis of PCA and HCA.

\section{Results and discussion}

\subsection{Bioactive compounds in the frozen fruit pulps}

A wide variation was found in the contents of: total phenolic compounds, from 6 (watermelon) to 658 (acerola) mg GAE/100 g pulp of; total flavonoids, from 1 (coconut and watermelon) to 134 (açai) mg CE/100 g pulp; and ascorbic acid from not detected levels to 506 (acerola) mg of ascorbic acid/100 $\mathrm{g}$ of pulp (Table 2).

The TPC contents of frozen fruit pulps were similar to other values reported in the literature (KUSKOSKI et al., 2006; EVANGELISTA; VIEITES, 2006; SANTOS et al., 2008, 2010; GENOVESE et al., 2008; MEZADRI et al., 2008; DANTAS et al., 2010), except for the contents found by Melo et al. (2008a), who used catechin as the analytical standard. The contents of bioactive compounds in açai frozen pulp were related to the protective effects of the pulp against doxorubicin-induced in vivo DNA damage in liver and kidney cells (RIBEIRO et al., 2010).

With regard to ascorbic acid, the contents found for the frozen fruit pulps in the present study were higher than those found by Canuto et al. (2010) for the pulps of acerola $(378.5 \mathrm{mg}$
AA/100 g pulp), caja (0.3 mg AA/100 g pulp), cashew-apple (12.4 mg AA/100 g pulp), and tamarind (0.1 mg AA/100 g pulp); while lower than those of açai (10.1 mg AA/100 g pulp) and of cupuaçu pulps (3.3 mg AA/100 g pulp). Ascorbic acid was not detected in açai pulp by Hassimotto, Genovese and Lajolo (2005) either; however, the values for frozen pulps of guava (49.9 mg AA/100 g pulp), cashew-apple (195 mg AA/100 g pulp), and acerola (885 mg AA/100 g pulp) were higher than those found in the present study.

In general, the great variation in the contents of bioactive compounds between the analyzed frozen fruit pulps can be associated to intrinsic (species, cultivar, and maturity stage) and extrinsic characteristics (environmental conditions, storage, and processing) of each fruit pulp and can lead to the variability in the composition of both the fresh fruit and processed products, including the frozen fruit pulp (KING; YOUNG, 1999; TOMÁSBARBERÁN; ESPÍN, 2001; BALASUNDRAM; SUNDRAM; SAMMAM, 2006). Furthermore, the difference between the contents of bioactive compounds in the frozen fruit pulps found in this study and the contents reported in the literature may be explained due to the different extraction methods of these bioactive compounds.

\subsection{Antioxidant capacity against the reactive oxygen species (ROS)}

When the antioxidant capacity of bioactive compounds is evaluated, an important factor to be considered is the scavenging mechanism against the specific analyzed reactive species. The $\mathrm{ROO}^{\circ}$ in the presence of an antioxidant, for example, is mainly scavenged by the hydrogen atom transfer; the scavenging mechanism against $\mathrm{H}_{2} \mathrm{O}_{2}$ probably occurs by the addition of this reactive species to the system of conjugated double bonds

Table 2. Contents of total phenolic compounds (TPC), total flavonoids (TF), and ascorbic acid (AA) from the frozen fruit pulps analyzed.

\begin{tabular}{lccc}
\hline \multicolumn{1}{c}{ Fruit pulp } & TPC $(\mathrm{mg} \mathrm{GAE} / 100 \mathrm{~g})$ & $\mathrm{TF}(\mathrm{mg} \mathrm{CE} / 100 \mathrm{~g})$ & $\mathrm{AA}(\mathrm{mg} / 100 \mathrm{~g})$ \\
\hline Açai & $251 \pm 64(26 \%)$ & $134 \pm 44(33 \%)$ & $\mathrm{nd}$ \\
Acerola & $658 \pm 179(27 \%)$ & $28 \pm 11(40 \%)$ & $506 \pm 54(11 \%)$ \\
Cacao & $29 \pm 5(17 \%)$ & $10 \pm 3(27 \%)$ & $\mathrm{nd}$ \\
Caja & $51 \pm 4(7 \%)$ & $11 \pm 3(24 \%)$ & $1 \pm 0(28 \%)$ \\
Cashew-apple & $95 \pm 13(14 \%)$ & $4 \pm 0.5(11 \%)$ & $167 \pm 24(14 \%)$ \\
Coconut & $10 \pm 4(45 \%)$ & $1 \pm 1(78 \%)$ & $7 \pm 3(42 \%)$ \\
Cupuaçu & $80 \pm 1(1 \%)$ & $29 \pm 2(6 \%)$ & $1 \pm 0(0 \%)$ \\
Guava & $88 \pm 39(45 \%)$ & $25 \pm 4(16 \%)$ & $29 \pm 3(9 \%)$ \\
Lemon & $8 \pm 2(18 \%)$ & $2 \pm 0.5(21 \%)$ & $1 \pm 0(0 \%)$ \\
Mango & $38 \pm 6(15 \%)$ & $6 \pm 1(21 \%)$ & $18 \pm 1(6 \%)$ \\
Orange & $66 \pm 4(7 \%)$ & $10 \pm 2(18 \%)$ & $62 \pm 9(15 \%)$ \\
Passion fruit & $26 \pm 2(6 \%)$ & $10 \pm 2(20 \%)$ & $7 \pm 4(59 \%)$ \\
Pineapple & $27 \pm 0.5(2 \%)$ & $5 \pm 2(35 \%)$ & $6 \pm 3(49 \%)$ \\
Pitanga & $73 \pm 5(7 \%)$ & $10 \pm 0.5(6 \%)$ & $12 \pm 4(31 \%)$ \\
Tamarind & $56 \pm 2(3 \%)$ & $24 \pm 3(11 \%)$ & $1 \pm 0(0 \%)$ \\
Tangerine & $46 \pm 15(33 \%)$ & $9 \pm 0(1 \%)$ & $58 \pm 9(15 \%)$ \\
Umbu & $20 \pm 11(56 \%)$ & $6 \pm 0.5(9 \%)$ & nd \\
Watermelon & $6 \pm 0(0,5 \%)$ & $1 \pm 0(5 \%)$ & nd \\
\hline
\end{tabular}

The values correspond to the mean \pm standard deviation (relative standard deviation) of two batches (each batch in triplicate); GAE = gallic acid equivalent. CE = catechin equivalent. nd $=$ not detected by the Tillman's method. 
of the antioxidant compound; while the ${ }^{\circ} \mathrm{OH}$ can be scavenged either by its addition to the conjugated double bonds or by hydrogen atom transfer of the bioactive compound (HUANG; OU; PRIOR, 2005; ANOUAR et al., 2009). All bioactive compounds determined in this study (TPC, TF, and AA) have the necessary structural characteristics to scavenge the analysed ROS, such as, hydroxyl groups and conjugated double bonds. In fact, in general, frozen fruit pulps presenting the highest contents of TPC, or TF, or AA are expected to be the most efficient scavengers of ROS.

The aqueous extracts of the 18 frozen fruit pulps also exhibited great variation in the values of antioxidant capacity against the analyzed ROS (Table 3 ).

The açai and acerola pulps, which had the highest TPC and TF contents (Table 2) among all pulps analyzed, were the most efficient scavenger of ROO ${ }^{\bullet}(7498$ and $6773 \mu \mathrm{mol}$ trolox $/ 100 \mathrm{~g}$ pulp, respectively). The values of scavenging capacity against the ROO* found in this study were in the same range as that reported for açai pulp $(9970 \mu \mathrm{mol}$ trolox/100 g pulp) (SCHAUSS et al., 2006), but higher than those found for acerola pulp (3458-5883 $\mu \mathrm{mol}$ trolox/100 g pulp) (MEZADRI et al., 2008). All other fruit pulps can be ranked according to the decreasing efficiency of ROO• scavenging capacity, as follows: tangerine, cupuaçu, orange, guava, cashew-apple, tamarind, pitanga, passion fruit, caja, cacao, mango, pineapple, umbu, lemon, watermelon, and coconut (Table 3 ).

With regard to the scavenging capacity against $\mathrm{H}_{2} \mathrm{O}_{2}$, the pulps of lemon, açaí, passion fruit, umbu, and pitanga had the highest efficiencies, i.e., the lowest $\mathrm{IC}_{50}$ values, varying from 143 (lemon) to $467 \mu \mathrm{g} / \mathrm{mL}$ (pitanga). On the other hand, the pulps of coconut and watermelon did not reach the $\mathrm{IC}_{50}$ value for $\mathrm{H}_{2} \mathrm{O}_{2}$ scavenging, showing efficiency of only $20 \%$ (coconut) and $27 \%$ (watermelon) at the highest tested concentrations (13847 and $16864 \mu \mathrm{g} / \mathrm{mL}$, respectively).

The pulps of açai, cupuaçu, acerola, guava, tamarind, and pitanga exhibited the lowest $\mathrm{IC}_{50}$ values of scavenging against $\cdot \mathrm{OH}$, varying from 3 (açai) to $89 \mu \mathrm{g} / \mathrm{mL}$ (pitanga), and thus they were the best scavengers of this species among the samples analyzed (Table 3).

As for the other frozen fruit pulps, the comparison with the literature data concerning the scavenging capacity against the analyzed ROS could not be made since either the applied methodology or the reactive species was different from those used in the present study

\subsection{Correlation and classification of frozen fruit pulps by multivariate statistical analysis}

In the PCA, the first two principal components (PC1 and $\mathrm{PC} 2$ ) accounted for $85 \%$ of the total explained variance (Figure 1).

According to the PCA, a positive correlation was observed between the scavenging capacity against ROO', and the contents of TPC $(r=0.82)$, TF $(r=0.81)$ and AA $(r=0.58)$ (Figure 1). These correlation values show that the TPC, including the TF, make the highest contribution to the antioxidant capacity against ROO', probably due to the excellent capacity of this class of bioactive compounds to transfer hydrogen atom, whilst AA presented the lowest contribution. Similar results were previously reported for 12 different fruits, with high positive correlation between the TPC and the antioxidant

Table 3. Scavenging capacities of frozen fruit pulps against peroxyl radical (ROO•), hydrogen peroxide $\left(\mathrm{H}_{2} \mathrm{O}_{2}\right)$ and hydroxyl radical $(\bullet \mathrm{OH})$.

\begin{tabular}{|c|c|c|c|}
\hline Fruit pulp & $\mathrm{ROO}^{\bullet}(\mu \mathrm{mol} \text { trolox } / 100 \mathrm{~g})^{1}$ & $\mathrm{H}_{2} \mathrm{O}_{2}\left(\mathrm{IC}_{50}=\mu \mathrm{g} / \mathrm{mL}\right)^{2}$ & $\cdot \mathrm{OH}\left(\mathrm{IC}_{50}=\mu \mathrm{g} / \mathrm{mL}\right)^{2}$ \\
\hline Açai & $7498 \pm 2509(33 \%)$ & $259 \pm 102(39 \%)$ & $3 \pm 1(36 \%)$ \\
\hline Acerola & $6773 \pm 74(1 \%)$ & $531 \pm 126(24 \%)$ & $45 \pm 4(10 \%)$ \\
\hline Cacao & $859 \pm 109(13 \%)$ & $2049 \pm 250(12 \%)$ & $150 \pm 48(32 \%)$ \\
\hline Caja & $883 \pm 190(22 \%)$ & $526 \pm 50(10 \%)$ & $116 \pm 27(23 \%)$ \\
\hline Cashew-apple & $1568 \pm 383(24 \%)$ & $2049 \pm 1038(51 \%)$ & $207 \pm 13(6 \%)$ \\
\hline Coconut & $166 \pm 43(26 \%)$ & $13847 \pm 1664(12 \%)^{3}$ & $447 \pm 74(16 \%)$ \\
\hline Cupuaçu & $1935 \pm 144(7 \%)$ & $700 \pm 81(12 \%)$ & $37 \pm 15(41 \%)$ \\
\hline Guava & $1575 \pm 249(16 \%)$ & $1454 \pm 148(10 \%)$ & $65 \pm 19(29 \%)$ \\
\hline Lemon & $240 \pm 3(1 \%)$ & $143 \pm 2(1 \%)$ & $206 \pm 23(11 \%)$ \\
\hline Mango & $635 \pm 50(8 \%)$ & $3318 \pm 88(3 \%)$ & $415 \pm 11(3 \%)$ \\
\hline Orange & $1678 \pm 52(3 \%)$ & $1552 \pm 402(26 \%)$ & $164 \pm 43(26 \%)$ \\
\hline Passion fruit & $923 \pm 125(14 \%)$ & $390 \pm 49(12 \%)$ & $205 \pm 4(2 \%)$ \\
\hline Pineapple & $626 \pm 254(41 \%)$ & $1631 \pm 74(5 \%)$ & $187 \pm 66(35 \%)$ \\
\hline Pitanga & $953 \pm 166(17 \%)$ & $467 \pm 20(4 \%)$ & $89 \pm 9(10 \%)$ \\
\hline Tamarind & $1164 \pm 132(11 \%)$ & $572 \pm 14(2 \%)$ & $75 \pm 5(7 \%)$ \\
\hline Tangerine & $1940 \pm 487(25 \%)$ & $1366 \pm 301(22 \%)$ & $139 \pm 14(10 \%)$ \\
\hline Umbu & $486 \pm 58(12 \%)$ & $418 \pm 86(21 \%)$ & $206 \pm 19(9 \%)$ \\
\hline Watermelon & $173 \pm 24(14 \%)$ & $16864 \pm 2819(17 \%)^{4}$ & $313 \pm 34(11 \%)$ \\
\hline
\end{tabular}

The values correspond to the mean \pm standard deviation (relative standard deviation) from two batches (each batch in triplicate). ${ }^{1}$ Trolox equivalent; ${ }^{2} \mathrm{IC}_{50}=$ Inhibitory concentration necessary to decrease $50 \%$ the oxidative effect of reactive species in the tested media; ${ }^{3}$ the inhibition at the highest tested concentration $(13846.50 \mu \mathrm{g} / \mathrm{mL})$ was $20 \%$; ${ }^{4}$ the inhibition at the highest tested concentration $(16863.50 \mu \mathrm{g} / \mathrm{mL})$ was $27 \%$. 


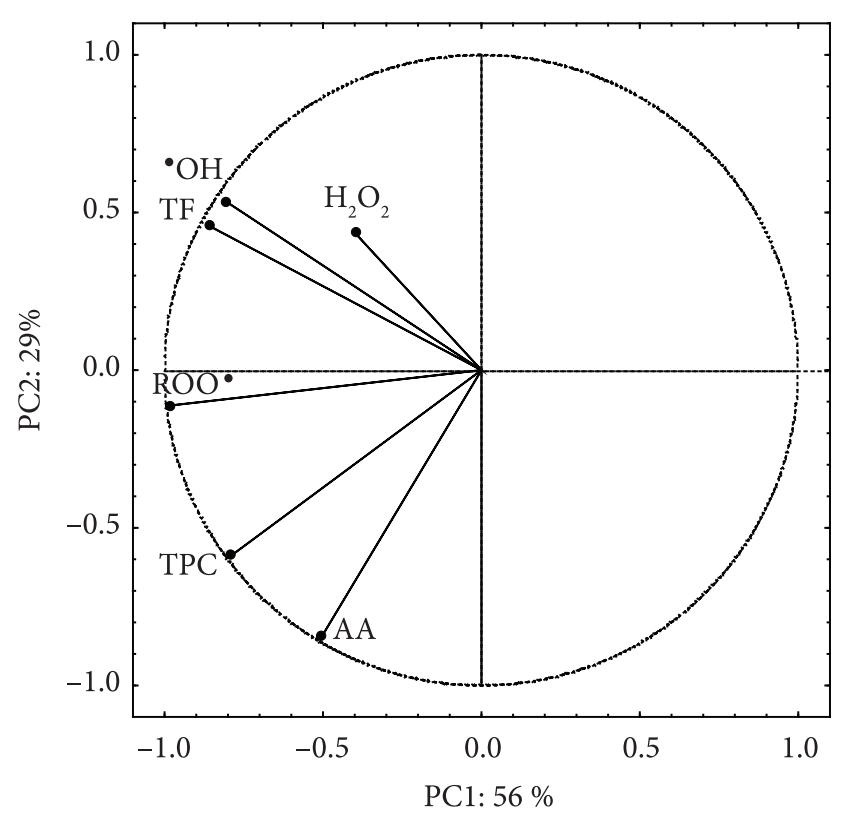

Figure 1. Variable projections in the PCA analysis obtained from the contents of bioactive compounds and the values of scavenging capacity against ROS for the 18 frozen fruit pulps analyzed. capacity against $\mathrm{ROO}^{\bullet}$ (also determined by ORAC assay) and low contribution of AA to the scavenging capacity against the oxidizing effect of ROO` (WANG; CAO; PRIOR, 1996).

With regard to the scavenging capacity against $\mathrm{H}_{2} \mathrm{O}_{2}$, no significant correlation was observed for TF $(\mathrm{r}=0.37)$, TPC $(r=0.12)$, and AA $(r=-0.06)$. Therefore, the bioactive compounds considered in this study do not contribute greatly to the scavenging capacity of this specific ROS. On the other hand, carbohydrates, proteins, and amino acids are also components of the extracts and therefore can play a great hole in its scavenging capacity against $\mathrm{H}_{2} \mathrm{O}_{2}$ since these compounds have been previously reported as efficient scavengers of ROS (PATTISON; DAVIES, 2006). For example, annatto seed extracts, which have both phenolic compounds (minor compounds) and carotenoids (major compounds) exhibited higher scavenging capacity against $\mathrm{H}_{2} \mathrm{O}_{2}$ ( $\mathrm{IC}_{50}$ from 11 to $47 \mu \mathrm{g} / \mathrm{mL}$ ) (CHISTÉ et al., 2011) than those of the 18 frozen fruit pulps analyzed in this study. Moreover, $\mathrm{H}_{2} \mathrm{O}_{2}$ is rather inert at low concentrations, and its oxidation power is believed to be observed in combination with $\mathrm{Fe}(\mathrm{II})$ through Fenton reaction (HUANG; OU; PRIOR, 2005).

As for the scavenging capacity against ${ }^{\circ} \mathrm{OH}$, a high positive correlation was observed with $\mathrm{TF}(\mathrm{r}=0.97)$, and no significant correlation was found for TPC $(r=0.31)$ and $\mathrm{AA}(\mathrm{r}=-0.06)$. In

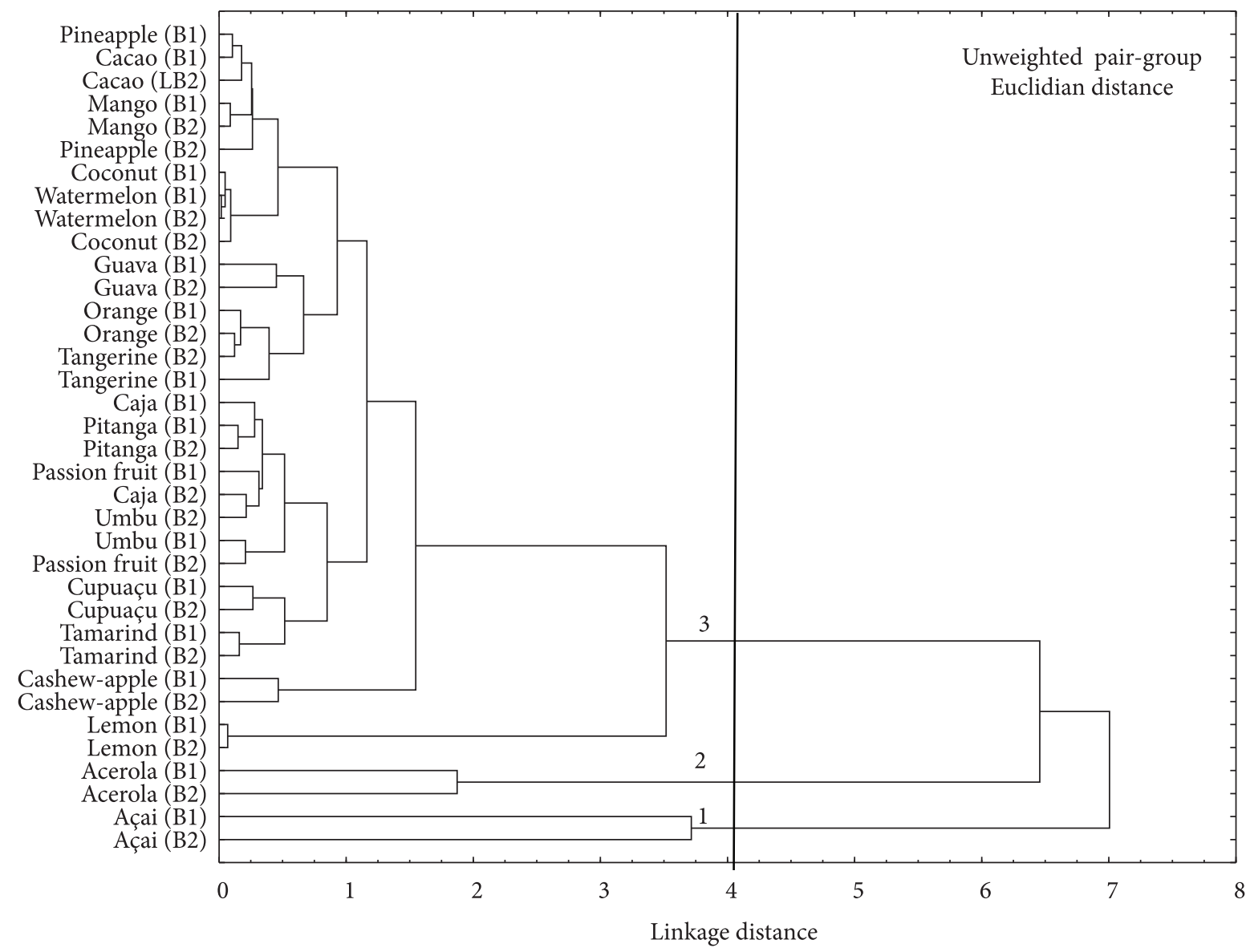

Figure 2. Dendrogram obtained by HCA analysis, considering the content of bioactive compounds and the values of scavenging capacity, against the tested ROS, for the 18 frozen fruit pulps analyzed in two different batches (B1 e B2). 

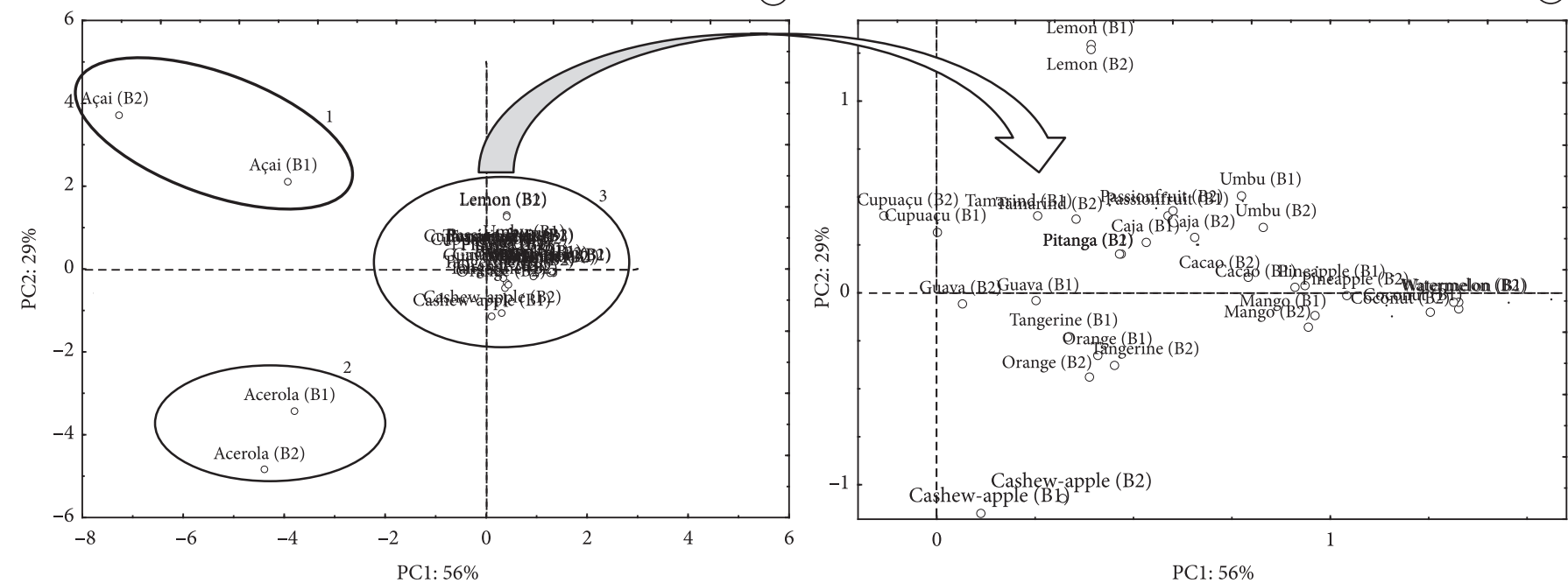

Figure 3. a) Scatterplot for samples by PCA analysis with suggested drawn grouping ellipses (by HCA) and b) expansion of the third group, both obtained from the results of bioactive compounds and scavenging capacity against the ROS for the different extracts of frozen fruit pulps of two different batches (B1 e B2).

this study, the $\mathrm{FeCl}_{2}-\mathrm{EDTA}-\mathrm{H}_{2} \mathrm{O}_{2}$ (Fenton reaction), the most used system to generate ${ }^{\circ} \mathrm{OH}$, was also used. However, this generation mode has disadvantages because many antioxidants, such as some classes of flavonoids, are also metal chelators. When the antioxidant is mixed with $\mathrm{Fe}$ (II), it may alter the activity of $\mathrm{Fe}(\mathrm{II})$ by chelation, and as a result, it is impossible to distinguish whether the antioxidants are simply good metal chelators or ${ }^{\bullet} \mathrm{OH}$ scavengers (HUANG; OU; PRIOR, 2005). This fact can explain the high correlation found between the contents of TF and the values of scavenging capacity against ${ }^{\circ} \mathrm{OH}$ since flavonoids are known to be good metal chelators. In addition, some compounds in foods, such as ascorbic acid, may act as pro-oxidants by reducing $\mathrm{Fe}(\mathrm{III})$ to $\mathrm{Fe}(\mathrm{II})$ and make the ${ }^{\circ} \mathrm{OH}$ generation catalytic (HUANG; OU; PRIOR, 2005).

The dendrogram obtained when HCA analysis was applied, allowed the classification of the 18 frozen fruit pulps into three groups, considering the contents of TPC, TF, AA, and the scavenging capacities against the different ROS. In addition, similarities between the two batches (B1 and B2) for all pulps were observed (Figure 2). The three groups could be clearly observed in PCA scatterplot (Figure 3).

The first group was formed by the açai pulp, with the highest content of TF (134.02 mg CE/100 g pulp) and the highest scavenging capacities against $\mathrm{ROO}^{\bullet}$ and ${ }^{\circ} \mathrm{OH}$; the second one was formed by the acerola pulp, due to the high contents of TPC (658.40 mg GAE/100 g pulp) and AA (506.27 mg/100 g pulp); and the third group was formed by the other fruit pulps which could not be separated considering only the contents of bioactive compounds and the values of scavenging capacities against the tested ROS (Figures 2 and 3, Table 2).

Considering the third group, the lemon and cashew-apple pulps showed a slight tendency to be separated from the other fruit pulps in this group, most probably due to the high scavenger capacity against $\mathrm{H}_{2} \mathrm{O}_{2}\left(\mathrm{IC}_{50}=142.70 \mu \mathrm{g} / \mathrm{mL}\right)$ of lemon pulp and to the high content of AA (166.56 mg AA/100 g pulp) found in the cashew-apple pulp (Figures 2 and 3, Table 2 and 3).

\section{Conclusions}

The frozen fruit pulps contain bioactive compounds which are in vitro scavengers of reactive oxygen species of biological importance, namely the $\mathrm{ROO}^{\bullet}, \mathrm{H}_{2} \mathrm{O}_{2}$, and ${ }^{\bullet} \mathrm{OH}$. In general, the scavenging capacities against $\mathrm{ROO}^{\circ}, \mathrm{H}_{2} \mathrm{O}_{2}$ and ${ }^{\circ} \mathrm{OH}$ species, as well as the concentrations of bioactive compounds, varied widely among the 18 different fruit pulps. This study confirmed the positive correlation between high levels of phenolic compounds, especially flavonoids, and the capacity to scavenge ROO'. Furthermore, the results indicated that the flavonoids show high scavenging capacity against ${ }^{\circ} \mathrm{OH}$, but they are less efficient against $\mathrm{H}_{2} \mathrm{O}_{2}$. In addition, ascorbic acid showed little contribution against all of the ROS studied. Among the 18 frozen fruit pulps evaluated, açai can be considered the best ROS scavenger.

\section{Acknowledgements}

The authors are grateful for the financial support provided by the foundations $\mathrm{CNPq}$ (Conselho Nacional de Desenvolvimento Científico e Tecnológico) and FAPESP (Fundação de Amparo à Pesquisa do Estado de São Paulo).

\section{References}

ANOUAR, E. et al. New aspects of the antioxidant properties of phenolic acids: a combined theoretical and experimental approach. Physical Chemistry Chemical Physics, v. 11, p. 7659-7668, 2009. PMid:19950505. http://dx.doi.org/10.1039/b904402g

BALASUNDRAM, N.; SUNDRAM, K.; SAMMAM, S. Phenolic compounds in plants and agri-industrial by-products: antioxidant activity, occurrence, and potential uses. Food Chemistry, v. 99, p. 191-203, 2006. http://dx.doi.org/10.1016/j.foodchem.2005.07.042 
BARRETO, G. P. M.; BENASSI, M. T.; MERCADANTE, A. Z. Bioactive compounds from several tropical fruits and correlation by multivariate analysis to free radical scavenger activity. Journal of the Brazilian Chemical Society, v. 20, p. 1856-1861, 2009. http:// dx.doi.org/10.1590/S0103-50532009001000013

CANUTO, G. A. et al. Caracterização físico-química de polpas de frutos da Amazônia e sua correlação com a atividade anti-radical livre. Revista Brasileira de Fruticultura, v. 32, p. 1196-1205, 2010. http://dx.doi.org/10.1590/S0100-29452010005000122

CHISTÉ, R. C. et al. In vitro scavenging capacity of annatto seed extracts against reactive oxygen and nitrogen species. Food Chemistry, v. 127, p. 419-426, 2011. http://dx.doi.org/10.1016/j. foodchem.2010.12.139

CONTRERAS-CALDERÓN, J. et al. Antioxidant capacity, phenolic content and vitamin $\mathrm{C}$ in pulp, peel and seed from 24 exotic fruits from Colombia. Food Research International, v. 44, p. 2047-2053, 2011. http://dx.doi.org/10.1016/j.foodres.2010.11.003

DANTAS, R. L. et al. Perfil da qualidade de polpas de frutas comercializadas na cidade de Campina Grande/PB. Revista Verde, v. 5, p. 61-66, 2010.

EVANGELISTA, R. M.; VIEITES, R. L. Avaliação da qualidade de polpa de goiaba congelada comercializada na cidade de São Paulo. Segurança Alimentar e Nutricional, v. 13, p. 76-81, 2006.

FU, L. et al. Antioxidant capacities and total phenolic contents of 62 fruits. Food Chemistry, v. 129, p. 345-350, 2011. http://dx.doi. org/10.1016/j.foodchem.2011.04.079

GARCÍA-ALONSO, M. et al. Evaluation of the antioxidant properties of fruits. Food Chemistry, v. 84, p. 13-18, 2004. http://dx.doi. org/10.1016/S0308-8146(03)00160-2

GENOVESE, M. I. et al. Bioactive compounds and antioxidant capacity of exotic fruits and commercial frozen pulps from Brazil. Food Science and Technology International, v. 14, p. 207-214, 2008. http://dx.doi.org/10.1177/1082013208092151

GOMES, A. et al. Antioxidant activity of $\beta$-blockers: an effect mediated by scavenging reactive oxygen and nitrogen species? Bioorganic \& Medicinal Chemistry, v. 14, p. 4568-4577, 2006. PMid:16510286. http://dx.doi.org/10.1016/j.bmc.2006.02.023

GOMES, A. et al. 2-Styrylchtomones: novel strong scavengers of reactive oxygen and nitrogen species. Bioorganic \& Medicinal Chemistry, v. 15, p. 6027-6036, 2007. PMid:17624791. http://dx.doi. org/10.1016/j.bmc.2007.06.046

HASsimotTO, N. M. A.; GENOVESE, M. I.; LAJOLO, F. M. Antioxidant activity of dietary fruits, vegetables and commercial frozen fruit pulps. Journal of Agricultural and Food Chemistry, v. 53, p. 2928-2935, 2005. PMid:15826041. http://dx.doi. org/10.1021/jf047894h

HUANG, D. et al. High-throughput assay of oxygen radical absorbance capacity (ORAC) using a multichannel liquid handling systems coupled with a microplate fluorescence reader in 96-well format. Journal of Agricultural and Food Chemistry, v. 50, p. 4437-4444, 2002. PMid:12137457. http://dx.doi.org/10.1021/ jf0201529

HUANG, D.; OU, B.; PRIOR, R. L. The chemistry behind antioxidant capacity assays. Journal of Agricultural and Food Chemistry, v. 53, p. 1841-1856, 2005. PMid:15769103. http://dx.doi.org/10.1021/ jf030723c

INSTITUTO ADOLFO LUTZ - IAL. Normas analíticas do Instituto Adolfo Lutz: Métodos químicos e físicos para análises de alimentos. 4. ed. São Paulo: IAL, 2004. p. 652-654.
KING, A.; YOUNG, G. Characteristics and occurrence of phenolic phytochemicals. Journal of the American Dietetic Association, v. 99, p. 213-218, 1999. http://dx.doi.org/10.1016/S00028223(99)00051-6

KIST, B. B. et al. Anuário Brasileiro de Fruticultura. Santa Cruz do Sul: Editora Gazeta, 2012. 128 p.

KUSKOSKI, E. M. et al. Frutas tropicais silvestres e polpas de frutas congeladas: atividade antioxidante, polifenóis e antocianinas. Ciência Rural, v. 36, p. 1283-1287, 2006. http://dx.doi.org/10.1590/ S0103-84782006000400037

MEDINA, A. L. et al. Araçá (Psidiumcattleianum Sabine) fruit extracts with antioxidant and antimicrobial activities and antiproliferative effect on human cancer cells. Food Chemistry, v. 18, p. 916-922, 2011. http://dx.doi.org/10.1016/j.foodchem.2011.03.119

MELO, E. A. et al. Teor de fenólicos totais e capacidade antioxidante de polpas congeladas de frutas. Alimentação e Nutrição, v. 19, p. 67-72, 2008a.

MELO, E. A. et al. Capacidade antioxidante de frutas. Revista Brasileira de Ciências Farmacêuticas, v. 44, p. 193-201, 2008b. http://dx.doi.org/10.1590/S1516-93322008000200005

MEZADRI, T. et al. Antioxidant compounds and antioxidant activity in acerola (Malpighia emarginata DC.) fruits and derivatives. Journal of Food Composition and Analysis, v. 21, p. 282-290, 2008. http:// dx.doi.org/10.1016/j.jfca.2008.02.002

PATTISON, D. J.; DAVIES, M. J. Reactions of myeloperoxidasederived oxidants with biological substrates: gaining chemical insight into human inflammatory diseases. Current Medicinal Chemistry, v. 13, p. 3271-3290, 2006. PMid:17168851. http://dx.doi. org/10.2174/092986706778773095

RIBEIRO, J. C. et al. Evaluation of the genotoxic and antigenotoxic effects after acute and subacute treatments with açai pulp (Euterpe oleracea Mart.) on mice using the erythrocytes micronucleus test and the comet assay. Mutation Research, v. 695, p. 22-28, 2010. PMid:19892033. http://dx.doi.org/10.1016/j.mrgentox.2009.10.009

RODRIGUES, E. et al. Microcapsules containing antioxidant molecules as scavengers of reactive oxygen and nitrogen species. Food Chemistry, v. 134, p. 704-711, 2012. PMid:23107681. http://dx.doi. org/10.1016/j.foodchem.2012.02.163

ROP, O. et al. Antioxidant properties of European cranberry bush fruit (Viburnum opulusvar. edule). Molecules, v. 15, p. 4467-4477, 2010. PMid:20657454. http://dx.doi.org/10.3390/molecules15064467

SANTOS, G. M. et al. Correlação entre atividade antioxidante e compostos bioativos de polpas comerciais de açaí. Archivos Latino Americanos de Nutricion, v. 58, p. 187-192, 2008. PMid:18833997.

SANTOS, G. M. et al. Atividade antioxidante e correlação com componentes bioativos de produtos comerciais de cupuaçu. Ciência Rural, v. 40, p. 1636-1642, 2010. http://dx.doi.org/10.1590/S010384782010005000103

SCHAUSS, A. G. et al. Antioxidant capacity and other bioactivities of the freeze-dried Amazonian palm berry, Euterpe oleraceae Mart. (acai). Journal of Agricultural and Food Chemistry, v. 54, p. 8604-8610, 2006. PMid:17061840. http://dx.doi.org/10.1021/ jf0609779

SINGLETON, V. L.; ROSSI, J. A. Colorimetry of total phenolics with phosphomolybdic-phosphotungstic acid reagents. American Journal of Enology and Viticulture, v. 16, p. 144-158, 1965.

TOMÁS-BARBERAN, F.; ESPÍN, J. C. Phenolic compounds and related enzymes as determinants of quality in fruits and vegetables. Journal of Science and Food Agriculture, v. 81, p. 853-876, 2001. http:// dx.doi.org/10.1002/jsfa.885 
WANG, H.; CAO, G.; PRIOR, R. L. Total antioxidant capacity of fruits. Journal of Agricultural and Food Chemistry, v. 44, p. 701-705, 1996. http://dx.doi.org/10.1021/jf950579y

WU, X. et al. Lipophilic and hydrophilic antioxidant capacities of common foods in the United States. Journal of Agricultural and Food Chemistry, v. 52, p. 4026-4037, 2004. PMid:15186133. http:// dx.doi.org/10.1021/jf049696w
XEYLA, R. Brasil é o terceiro maior produtor de frutas do mundo. 2009. Disponível em: <www.ecodebate.com.br>. Acesso em: 06 abr. 2011.

ZHISHEN, J.; MENGCHENG, T.; JIANMING, W. The determination of flavonoid contents in mulberry and their scavenging effects on superoxide radicals. Food Chemistry, v. 64, p. 555-559, 1999. http:// dx.doi.org/10.1016/S0308-8146(98)00102-2 